Headquarters: Parkring 8, POB 995, A-1011 Vienna, Austria. Website: http://www.ofid.org

Email: info@ofid.org

Director-General: Suleiman Jasir al-Herbish (Saudi Arabia).

\section{Environmental Organizations}

\section{Friends of the Earth International}

Origin. Friends of the Earth was founded in 1971 by a network of environmental activists from France, Sweden, the UK and the USA.

Mission. The organization aims to 'collectively ensure environmental and social justice, human dignity, and respect for human rights and peoples' rights so as to ensure sustainable societies'.

Organization. Friends of the Earth International comprises 74 national member groups, with a combined membership of individuals exceeding $2 \mathrm{~m}$. around the world in some 5,000 local activist groups. A small, central secretariat operates out of Amsterdam in the Netherlands and co-ordinates major campaigns, but grassroots activities are tailored by the relevant national or regional group.

Headquarters: Nieuwe Looiersstraat 31, 1017 VA Amsterdam, Netherlands.

Website: http://www.foei.org

Chair: Jagoda Munić (Croatia).

\section{Global Environment Facility (GEF)}

Origin. The Global Environment Facility is an independent financial organization that brings together 183 countries in partnership with international institutions, civil society bodies and the private sector to address global environmental issues and support national development initiatives. It was established in 1991 under the aegis of the World Bank, becoming a permanent, separate institution in 1994.

Activities. As of Feb. 2014 the GEF had provided US\$11.5bn. in grants and co-financed over 3,000 projects in some 165 countries totalling US $\$ 57 \mathrm{bn}$. since 1991 . It also serves as the financial mechanism for the Convention on Biological Diversity, the UN Framework Convention on Climate Change, the Stockholm Convention on Persistent Organic Pollutants, the UN Convention to Combat Desertification and the Minamata Convention on Mercury (an agreement to protect human health and the environment from the effects of mercury emissions).

Organization. There is a GEF Assembly comprising representatives of each member country that meets every three to four years. The GEF Council is the main governing body, developing, adopting and evaluating specific programmes. The secretariat is based in Washington, D.C., and there are also a scientific and technical advisory panel, an evaluation office and a number of agencies managing particular projects.

Headquarters: 1818 H Street, NW, Mail Stop P4-400,

Washington, D.C., 20433, USA.

Website: http://www.thegef.org

Chief Executive Office and Chair: Dr Naoko Ishii (Japan).

\section{Greenpeace International}

Origin. Greenpeace evolved out of a series of environmental and anti-nuclear protests in Canada in the late 1960s and early 1970s. In 1985 it became the focus of international attention when agents of the French security services blew up the organization's flagship, Rainbow Warrior, while it was in Auckland Harbour, New Zealand.

Mission. Greenpeace is an independent global environmental organization that aims to secure a planet 'that is ecologically healthy and able to nurture life in all its diversity'. It campaigns to: prevent pollution and abuse of the Earth's land, oceans, air and fresh water; end all nuclear threats; and promote peace, global disarmament and non-violence.

Organization. Greenpeace International has its headquarters in Amsterdam in the Netherlands, from where it co-ordinates worldwide campaigns and monitors and advises 28 national and regional offices. These provide a presence in over 40 countries.

Financial contributions from governments, political parties and commercial organizations are not accepted. Funding is provided by individual supporters and foundation grants. In the 18 months to Jan. $2009,2.9 \mathrm{~m}$. people took out or renewed financial membership.

Headquarters: Ottho Heldringstraat 5, 1066 AZ Amsterdam,

Netherlands.

Website: http://www.greenpeace.org

Executive Director: Kumi Naidoo (South Africa).

\section{World Wide Fund for Nature (WWF)}

Origin. WWF was officially formed and registered as a charity on 11 Sept. 1961. The first National Appeal was launched in the United Kingdom on 23 Nov. 1961, shortly followed by the United States and Switzerland.

Mission. WWF has as its mission preserving genetic, species and ecosystem diversity; ensuring that the use of renewable natural resources is sustainable now and in the longer term, for the benefit of all life on Earth; promoting actions to reduce to a minimum pollution and the wasteful exploitation and consumption of resources and energy. WWF's ultimate goal is to stop, and eventually reverse, the accelerating degradation of our planet's natural environment, and to help build a future in which humans live in harmony with nature.

Organization. WWF is the world's largest and most experienced independent conservation organization with over $4.7 \mathrm{~m}$. supporters and a global network of 27 National Organizations, five Associates and 24 Programme Offices.

The National Organizations carry out conservation activities in their own countries and contribute technical expertise and funding to WWF's international conservation programme. The Programme Offices implement WWF's fieldwork, advise national and local governments, and raise public understanding of conservation issues.

Address: Avenue du Mont-Blanc, CH-1196 Gland, Switzerland. Website: http://wwf.panda.org

Director General: James P. Leape (USA).

President Emeritus: HRH The Prince Philip, Duke of Edinburgh.

President: Yolanda Kakabadse (Ecuador).

\section{Treaties}

\section{Antarctic Treaty}

Antarctica is an island continent some $15.5 \mathrm{~m}$. sq. $\mathrm{km}$ in area which lies almost entirely within the Antarctic Circle. Its surface is composed of an ice sheet over rock, and it is uninhabited except for research and other workers in the course of duty. It is in general ownerless: for countries with territorial claims, see 